\title{
Virginity Test in Police Recruitment System: Evidence from Indonesia
}

\author{
Manotar Tampubolon \\ Faculty of Law, Universitas Kristen Indonesia, Jakarta, Indonesia \\ justitie234@gmail.com
}

\begin{abstract}
It is difficult for women to become police officers in Indonesia. One of the mandatory requirements is to become a virgin. Women who are no longer virgins cannot pass the selection. However, if the woman's hymen is damaged not because of sexual intercourse but because of an accident, she still hopes to become a police officer. This study aims to examine the virgin criteria as a requirement to become a policewoman in Indonesia. This quantitative study examines the virginity for police admission based on virginity requirements from a human rights perspective and the concept of innocence. Inspired by the idea of purity from Hanne Blank that celibacy does not reflect a known biological necessity and provides no demonstrable evolutionary advantage. This article says that police virginity testing is not essential and makes up discrimination of women's opportunity to become a police officer because there is no correlation between virginity and police duty. This article evaluates this activity performed Indonesian police force from the lights of human rights. It criticizes the policy development specification of Indonesia which is even poor than India and Muslim countries as even in this country women empowerment is prioritized and respected. This country is needed to incorporate changes in this policy.
\end{abstract}

Keywords

virginity; policewomen; discrimination; women rights; Indonesia

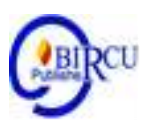

\section{Introduction}

In the modern legal environment, gender discrimination is highly prioritized in every professional sector. However, being a developed country Indonesia has reflected very stagnant and primitive regulation by considering virginity tests for women candidates willing to join the police force. A very stereotypical viewpoint is responsible behind such kind of policy development that can be also seen as prejudice. Wibawa (2018) stated that Indonesian police authority considers that society will prefer female policies officers if only they have no proof of active physical relations and history of having physical relationships.

As suggested by Cochrane (2014) women under polices force are subjected to virginity test since 1965 when police force was placed under command of military. Indonesian police believe that virginity signifies that a girl can protect herself thus she can protect others which reflect highly unscientific logic behind permitting such disgraceful act. Women police officers are not even permitted to get married in first two years of service as getting married will reflect the presence of physical relationship thus the officer will not be considered as pure furthers well as impair their beauty (Shedden, 2018).

As per police official this test is necessary for examining morals of a women candidate however virginity test do not signify morals of individual (O'Connell, 2018). This test is conducted saying it is a medical test in an official document and all-female 
candidates willing to become a police officer are mandatorily needed to participate in this test for proving her virginity, as well as her eligibility to perform duties of the police officer (Siddhartha, 2018).

The international human right council have raised question against this disgraceful act reflecting it as sexual harassment which is sexual harassment. Afrianty (2020) suggested that women have always played vital role in bringing democratic changes Indonesia thus humiliating women through such tests are disgraceful. Having a pretty face and good figure is vital for becoming a female police officer in Indonesia (Davis, 2020). Police force of this country is conducting this test even WHO declared this test as meaningless 3 years ago (India today, 2017). Crosby et al. (2020) WHO signified the virginity test is gains human rights and medically unnecessary. Police officers are needed to be recruited based on the physical strength and capabilities to perform work associated with police duties. In this context considering virginity as well as the beauty of the female police officers as criteria for being selected as well as criteria for signifying self as capable to meet the duties of policies of reflects discrimination. Even in progressive countries such as India and Afghanistan, the government has created reservations in every local police territory for recruiting a minimum number of example candidates in the police (McDermott, 2015).

From this light, it can be reflected that being developed country as well as having a second-largest economy in Asia this country is still followers' stereotypical rules for recruiting women in the public service sector such as the police. As per Indonesian policy presence of intact hymen reflects the purity of women this policy believes that people will not communicate with female officers who are not beautiful and pure as per this disgraceful recruitment policy (Human Rights Watch, 2014). This policy reflects the stereotype that society only accepts good girls who are beautiful and have no history of physical relations. After identifying this stagnant and disrespectful act against women a US-based organization named Human Rights Watch has urged the president of Indonesia Joko Jokowi to demolish this disrespectful act towards women as gender-based violence. HRW signified that this disrespectful act is needed to be immediately banned as it is discriminating employment opportunities of Indonesian women as well as impairing basic rights of living life on their terms (The Jakarta Post, 2017). The virginity test is abusive and it is highly disrespectful for women of Indonesia and the government of this country is continuously tolerating this activity.

This research will demonstrate the various tests given by the women willing to become a police officer, gender discrimination for a women candidate in training, different laws guiding the procedure of selection. The study also describes the differences in law of Indonesia and India for selection of woman candidate, differences in practices related to recruitment of police in Muslim countries and Indonesia and the impact of gender discrimination of women at the time of applying for police officer in Indonesia. Different case studies have been selected and analysed to properly demonstrate the topic. In the end part of this research, corrective measurement is described to demolish the rule of virginity test for the women willing to be a police officer in Indonesia. The conclusion part describes the future scope and the declaration of conflict interest. 


\section{Review of Literature}

\subsection{Virginity as a Prerequisite}

Women who are willing to become a police force in Indonesia have to go through a very primitive test under the guise of morality and physical examination that reflects dictionary behaviours towards women. In this country, women are needed to go through two-finger virginity tests for proving their virginity and needed to fulfil all criteria associated with definition of pretty to be a part of police force. In Indonesia, it is a very challenging task for the women's who want to become a police officer. They must have to fulfil the criteria which are very much needed to become a police officer. First of all, they should be in the age of 17.5 to 22 years. Then there are other requirements like they much complete their high school graduation and a God-fearing person who have at least 6.5 inches of height. Also, they must be unmarried and 'Virgins' (Pratama, 2020), which is very much discriminatory and degrading.

According to the Indonesian national police job website, there is mentioned that female applicants must have to pass the "virginity tests" (Afrianty, 2020). That means all the women who want to serve the nation should keep their virginity. Several female candidates described the practice who is interviewed by HRW. According to them, first, they completely undress the candidates before entering the exam room and they also found it very upsetting. In this test, examiners insert two fingers into the vagina to see if the woman's hymen is still intact or not - which is not an accurate practice to determine a woman's virginity. Some of the candidates even fainted as the tests are very painful and humiliating. As said by Gleisner \& Siwe (2020) some of the participants who are not able to pass the examination also told the human rights that the tests are not conducted by a medical doctor, also they mentioned that the examiners also put their fingers into their anus.

When taking study on this some of the senior policewomen also told that they want this test should continue and according to them this test shows that the policewomen are capable to protect themselves as well the other peoples. It was also found that this test is also practised by the military forces of Indonesia. In the study it was also found that along with this test candidate must be in good physical health with a strong religious belief. Yi (2018) stated that military defended this practise explaining it is necessary for judging mentality of women recruits which is unscientific. If any of the criteria is found missing the women candidate are not able to become a part of the Indonesian police force.

\subsection{Virginity Test and Discriminatory Behaviour}

As coined by Bauer et al. (2017) consideration virginity test as well as meeting all criteria that define the term pretty significantly create discrimination between women as well as between men and women. candidates in police force are needed to be selected by their intelligence and physical capabilities however in this country women candidates are judged by their appearance and beauty which is severely unethical and discriminatory. The female candidates who are willing to serve their nation by became a part of police force have to survive several types of discriminatory behaviour. According to them the tests conducted by the selection committee are very degrading, discriminatory, traumatizing, and humiliating. The virginity tests are above all. These so-called virginity tests are very discriminatory and it is also a form of gender-based violence. It is not a very practical way to measure the eligibility of a woman who wants to make her career in police.

In other Muslim countries like UAE, Malaysia, Maldives and many other this type of tests are not performed when selecting a female candidate for the police force. The practice 
is very old and it is based on the belief that a virgin police officer is healthier than others and also, they morally fitter. Some of the officials said that this entire test is conducting to date to get the best applicants. Also, they said that under this test they also examine if the candidate has any other genital or urinal problem or they have any diseases or infections inside them. Ramadhan (2018) stated that Indonesia is willing to reform rape laws however still continuing disgraceful acts of virginity test in police recruitment. This reflects discrimination and inequality for women.

This practice is also conducted by the military forces of Indonesia. Many of the military generals believed that if the hymen is torn between from $11.00 \mathrm{am}$ to $02.00 \mathrm{pm}$, it means it was caused by physical activities but if the hymen is torn after $6.00 \mathrm{pm}$, it means the woman has a sexual life. It is very much unscientific and these are considering as a case of sexual violence. As said by Davies (2018) it is also seen that male police officers are also recording the bust size of female police officers and the female recruits must parade in front of them so the male officers can judge their beauty. After selecting in the police force the women must have to serve the nation by staying unmarried for the first two years and once married, they have to take permission letter from their husband to continue the job. When government officials have been contacted for a comment on this matter, they did not respond.

\subsection{Laws Guidling the Procedures for Selecting Women in Police Force in Indonesia}

No specific guidelines are highlighting the requirement of virginity tests for women candidate willing to join police force in Indonesia. As per human rights regulation, national police principles for recruitment are needed to be non-discriminatory and human. However Indonesian policy for recruiting women in police force can be defined as discriminatory and inhuman form lights of human rights (Satterth Waite, 2005). The basic requirements are:

1) Applicants must be a citizen of Indonesia.

2) They must have believed and fear the almighty God.

3) At least the age of 18 or at most 28 years old.

4) Not currently involved in any type of criminal activity and free from drug.

5) She must to be placed throughout the territory of the Unitary State of the Republic of Indonesia (NKRI) and willing to be assigned to a Work Unit (SATKER) according to the expertise or background of the study program.

6) She never has been member of the national police, minimum height of 155 (one hundred and fifty-five) $\mathrm{cm}$

7) They must have to pass the Panda levels with knockout that includes administrative examinations with qualitative assessments. Next is stage I health examination with qualitative and quantitative assessments, after that she must have to clear written psychological tests with qualitative and quantitative assessments. after completing this a Phase II health examinations with qualitative and quantitative assessments will be conducted and then a final administrative examination and determination of final graduation by qualitative assessment.

8) When passing the panda levels then comes the central level with a knockout system and or ranking system that includes, administrative examination with qualitative assessment. Also tracing social media track records with qualitative assessments. After that skill competency test (practice according to the profession/study program) with a qualitative assessment will be conducted. After passing the health examination I and II (including Keswa) with MS / TMS assessment with qualitative and quantitative assessments, psychological tests/interviews with qualitative and quantitative assessments, physical 
fitness test with quantitative assessment, determination of final graduation by qualitative assessment.

After passing all of these police verification will be conducted and if a candidate passed through all of these then she can be appointed as a police officer in Indonesia.

\subsection{Differences between Indian Laws and Indonesia Laws Guiding Recruitment of Women in Police Force}

Indian regulation guiding police recruitment such as the Police Act 1861 incorporated by British colonial regulations. That is amended by Supreme Court to include minimum number of women force in each state to strengthened police force (Goldfarb, 2002). Being developing country India is amending its regulations to include women in police force to reduce discrimination among both male and female candidates are judged by their intelligence and physical strength and not based on sexuality.

In 2020, the number of female police officers in Indonesia was recorded at 24,506 consisting of 3 high-ranking officers, 1567 middle officers, 355 first officers, and 19581 non-commissioned officers (Dewi, 2020). This figure is small when compared to all members of the Indonesian Police, which are recorded at around 440.000 personnel (Amaz, 2020). In India, out of a total of 20,91,488 personnel in the police force, the female force is 215,504 , constituting $10.3 \%$ of the uniformed service (The Wire, 2020). It is very important to increase the numbers of women in police so the state governments are now committed to increasing the numbers and they are maintaining the equitable balance of men and women. In India, the recruitment processes are conducting systematically. The police departments are creating combined posts to achieve the target to increase the numbers of policewomen in every post.

The recruitment process is currently based on caste, region and class, ethnicity and any other related factors. The police department also taking the help of local media and educational institutes to increase the opportunities for the women who want to join the forces. On the other hand, being a developed country presence of such discriminatory and inhuman policy for recruiting females in police is shameful for Indonesia. They are still conducting the so-called virginity tests. A retired women police officer said that this test was performed on her. Also, some of the women police officers are still fighting to demolish the practice. In 2009, Indonesian national police chief issued a new mechanism, the regulation number 5 , in which the female candidates must complete an obstetrics and gynaecology examination but also it does not specify that a test of virginity is to be administered. This test included as a part of applicant's physical examination. But still now in police medical centres or police conducted hospitals are performing these tests. When asking they said that they want to get rid of prostitutes among the applicants.

\subsection{Differences in Practices Associated With Recruitment of Women in Police Force in Muslin Countries and Indonesia}

Laws and regulation in Muslim countries and such as United Arab Emirates, Egypt and Saudi Arabia are managed by religious specifications. Muslim religion is considered to be very conservative towards women however from a positive site in can be seen that in recent years' women in such countries are doing well in public sector jobs such as police force. Even in such countries where women are prohibited and restricted from many activities are amending their laws for encouraging women to participate in practical filed jobs such as police and recruiting social discrimination based on gender. 


\subsection{Impact of Sexual Discrimination of Women}

Virginity tests are very painful and disrespectful towards dignity of women (Behrens, 2015). Indonesia polices for recruiting women in police has encouraged such practices for several years and current administration in the verge of answering the question of practising activities identifying sexual harassment and breaking human rights. This thing has affected both police officers and women from the general public. Women who have gone through test have signified this test as painful and traumatic procedure. This test also hampers good efforts to improve women's protection in Indonesia.

The women applicants who failed in this test were not necessarily expelled from the forces, also all the women described this test as very much painful and can give them trauma. In West Sumatra, the female police officers who are conducting this test felt guilty and they said that the state does not have trust in them who wanted to work professionally. But some policewomen feel that such tests must be conducted. They feel very proud to be virgins and also, they feel very sorry for their colleagues who are protesting for demolishing the virginity test.

\section{Research Methods}

The author considers a qualitative study and a gender perspective to justify the need to change the virginity testing process for female candidates wishing to join the police force in Indonesia. Stieglitz et al. (2018) suggested that this data collection and analysis method is particular to get data directly from the source. The author has carried out the thematic analysis in this study to verify the hypothesis. Ruggiano \& Perry (2019) suggest that in thematic analysis, it developed themes based on research objectives and objectives to provide an opportunity to distribute findings collected on a particular piece to access the desired explanation of the research objectives.

\section{Discussion}

\subsection{Virginity Test for Women is Against Human Rights}

In Indonesia women willing to pursue a career in the police force are needed to go through a virginity test named two-finger test in which the condition of the hymen is examined. Such humiliating and disrespectful tests are conducted by disguising it under medical tests. Such tests are conducted for proving the physical purity of the woman candidate willing to become a police officer. As per Indonesian policies for recruiting women in police force presence of virginity in a woman officer allow the women officer to be easily accepted by society. Such people experience lifetime trauma on female aspirants willing to become police officers (NPR, 2014).

This kind of activities clearly defines that there is the presence of discrimination based on gender and appearances as well as personal choice in this country. As stated by Islam \& Asadullah (2018) women rights highly protected by human rights related regulation and in the regulation activities that humiliate feminine gender such as virginity tests are strictly prohibited. However, being a developed country Indonesia is still following such distasteful activities. As mentioned by Daulay (2017) in countries such as Indonesia gender-based roles in society are still prioritised which signifies that this country has not become able to reform its society, as well as women in this country, are still dominated and discriminated based on gender speciation.

Even in developing countries such as India and muslin country in which religious regulation are very conservative towards women has reflected positive approaches for 
making society more progressive and empowering women by reducing discrimination. In this context, this activity of Indonesia can be considered as discriminatory toward women. As suggested by Davies \& Hartono (2015) gender-based roles are influenced by social stereotypes and gender-based roles impair opportunity of women to succeed in a career.

Presence of gender-based roles intent to discriminate against women from participating in career options that are making dominated such as army or police. Such tests in Indonesia are not even performed by female medical official even no medical officials are hired for conducting this test. Such kind of shameful experience influences lifetime trauma that signifies impairing psychological wellbeing that is against human rights related regulations (Human rights Watch, 2018). Prisco (2018) mentioned that the government of Indonesia has been urged to demolish this kind of policy that defames the police force of this country in front of our countries as well as question about the social development and social awareness of the country. Indeed, such countries raise questions about equality of opportunity and opportunity to perform basic human rights of women in this country.

\subsection{Virginity Test Creating Gender Discrimination}

Inequality and discrimination these two factors are highly against the values of human right. A virginity test is conducted through a two-finger test and this test is painful, humiliating as well as impaired dignity of women. Such policies and activities have created a discriminatory environment for women in Indonesia where no equal opportunity is present from women. Such kind of virginity tests are performed by males even female professionals are not arranged for conditioning such tests.

As per Indonesian policies society will only accept a female police officer who is beautiful and has no history of being engaged with physical intimacy. Even female police officers are not allowed to get married as after marriage they will not be virgin anymore. Such policies reflect the dark side of society and it reflects that people Indonesian are still submerged in prejudices and women are not properly treated in this country. Police authority of this country is needed to change this humiliating policy as it is against human rights as well as harms the dignity of women (World Health Organization, 2017). As per the human right regulation, every human being has their liberty choosing life choices of being married or unmarried and a workplace environment is needed to support life decisions of individuals without imposing barriers in liberty and lifestyle (Cole, 2017). Such gender-based discrimination and gender-based humiliating activities in impairing eligible and capable women from participating in the police force of Indonesia.

It can be identified that in Indonesia the virginity test signifies presence of genderbased discrimination and inequality. Such kinds of gender-based discrimination are strictly against international human rights-related laws and impair women rights. Consideration of such policies for recruiting women in the police force highlight that this country is even less progressive than Muslim countries as such countries have reflected positive movement for protecting women's dignity and women rights. 


\section{Conclusion}

Thus, it can be concluded that Indonesia needs to immediately change the policy of sending virginity tests for women willing to participate in the police force. This activity is against human rights and defames as well as impairs dignity of women. Such kind of activities influences lifetime trauma of females that impairs psychological wellbeing. Awareness among people of this country is needed to be increased for bringing changes in policies.

Human rights policies are needed to be implemented in this country for abandoning this disrespectful act of virginity test for women willing to become police officers in Indonesia. This matter needs to be taken to the international human rights council and based on the request this council will investigate to verify the matter of fact. After investigation, the human rights council will recommend the Indonesian government to ban the policy as this is highly disrespectful to women as well as impairs human rights of accessing liberty in lifestyle.

As suggested by McDougal, Lasswell \& Chen (2018) human rights in national policies can be implemented through some specific legal instruments. These legal instruments include the international bill of human rights, democracy and Security Council. Application of the human rights law for abandoning this policy of conducting virginity tests as well as bringing equality will be beneficial as not following international laws can lead Indonesia to huge compensation as well as criticism in the UN. As per human righteous democracy can be defined as universal value reflecting the free expression of the will of people for determining their own political, economic, social and cultural system. Accessing democratic rights in basic human rights under international human rights regulation and thus Indonesia can face international law related legal consequences (United Nations, 2021).

The Security Council will also ensure strict monitoring on government and legal authorities' move regarding this process of implementing changes in the disgraceful act of conducting virginity tests for women willing to become police officers. Most importantly it will be necessary to increase awareness among people of this country regarding the biological fact that virginity test is not a tool for judging capability of women to become a successful police officer rather this act is disrespectful and impairs women from accessing equal opportunity.

In this research to identify the discriminatory barriers faced by women willing to become a police officer in Indonesia has been considered. This research can be further improved by incorporating primary qualitative research methods in which interview and survey can be considered for incorporating the real-life experience of the women who have gone through inhuman acts of women in this country regarding this disrespectful act in Indonesia.

\section{References}

Afrianty, Dina. (2020). Rising public piety and the status of women in Indonesia two decades after reformasi. TRaNS: Trans -Regional and -National Studies of Southeast Asia, 8(1), 65-80. doi:10.1017/trn.2019.14

Bauer, Greta. R., Braimoh, Jessica., Scheim, Aiden. I.,and Dharma, Christoffer. (2017). Transgender-inclusive measures of sex/gender for population surveys: Mixedmethods evaluation and recommendations. PloS one, 12(5), e0178043. 
https://journals.plos.org/plosone/article?id=10.1371/journal.pone.0178043. Accessed 12 January 2021

Behrens, Kevin. G. (2015). Why physicians ought not to perform virginity tests. Journal of Medical Ethics, 41(8), 691-695. https://jme.bmj.com/content/medethics/41/8/691.full.pdf. Accessed 20 January 2021.

Blackburn, Susan. (2004). Women and the State in Modern Indonesia, Cambridge: Cambridge University Press.

Calamur, Krishnadev. (2014). Indonesia Urged to Stop 'Virginity Tests' for Female Police Recruits. NPR.18 November. https://www.npr.org/sections/thetwoway/2014/11/18/364982163/indonesia-urged-to-stop-virginity-tests-for-femalepolice-recruits.

Cochrane, Joe. (2014). Virginity Test Stokes Indonesia Debate. https://www.nytimes.com/2014/12/12/world/asia/for-police-career-in-indonesiasome-women-must-first-pass-virginity-test.html. The New York Times, 11 December.

Cole, Mike. (Ed.). (2017). Education, equality and human rights: issues of gender,'race', sexuality, disability and social class. Routledge, Abingdon, UK. http://ndl.ethernet.edu.et/bitstream/123456789/5959/1/233.pdf.pdf. Accessed 18 January 2021.

Crosby, Sondra. S., Oleng, Nicolette., Volpellier, Muriel. M.,and Mishori, Ranit. (2020). Virginity testing: recommendations for primary care physicians in Europe and North America. BMJ global health, 5(1), 1-6. doi:10.1136/ bmjgh-2019-002057

Davies, Sharin. G. (2018). Skins of morality: Bio-borders, ephemeral citizenship and policing women in Indonesia. Asian Studies Review, 42(1), 69-88. https://www.tandfonline.com/doi/abs/10.1080/10357823.2017.1407292

Davies, Sharin. G., and Hartono, H. S. (2015). The Pretty Imperative, Intersections: Gender and Sexuality in Asia and the Pacific, 1(37), 1-15. https://doi.org/10.1080/10357823.2017.1407292

Davis, Sharin.G. (2020). Beautiful virgins: the hard road to becoming an Indonesian policewoman. https://asaa.asn.au/tag/women-police-in-indonesia/

Dewi, Anita, P. (2020). Hari Jadi ke 72 Polwan, Kapolri minta polwan terus berkarya. Antaranews, September 1. https://www.antaranews.com/berita/1700206/hari-jadi-ke72-polwan-kapolri-minta-polwan-terus-

berkarya\#: :text=Saat\%20ini\%20jumlah\%20polwan\%20di,perwira\%20pertama\%20 dan\%2019.581\%20bintara.

Etikan, Ilker., \& Bala, Kabiru. (2017). Sampling and sampling methods. Biometrics \& Biostatistics International Journal, 5(6), 149-200. http://www.hmvelms.org/placement/admin/HUMANITIES/PSYCHOLOGY_1919.p df.

Farouk, Amaz. (2020). Polri Kekurangan 270.000 Personel, Termasuk 95.000 Perwira. Berita Satu, July 5. https://www.beritasatu.com/nasional/652343/polri-kekurangan270000-personel-termasuk-95000perwira\#: :text=Personel\%20Polri\%E2\%80\%94yang\%20jumlahnya\%20sudah,5\%2 F7\%2F2020).

Gleisner, Jenny., and Siwe, Karin. (2020). Differences in teaching female and male intimate examinations: a qualitative study. Medical education, 54(4), 348-355. https://www.academia.edu/download/62872966/Gleisner_Siwe_20202020040816548-wmb5ha.pdf 
Goldfarb, Sally. F. (2002). The Supreme Court, the Violence Against Women Act, and the Use and Abuse of Federalism. Fordham L. Rev., 71, 57. http://ir.lawnet.fordham.edu/cgi/viewcontent.cgi?article=3851\&context=flr

Hackett, Justin. D., Omoto, Allen. M., and Matthews, Miriam. (2015). Human rights: The role of psychological sense of global community. Peace and Conflict: Journal of Peace Psychology, 21(1), 47-70. DOI: 10.1037/pac0000086

Harsono, Andreas. Human Rights Watch. (2014). Indonesia: 'Virginity Tests' for Female Police. https://www.hrw.org/news/2014/11/17/indonesia-virginity-tests-femalepolice. Accessed 14 January 2021.

Howell, Julia. D. (2005). Muslims, the new age and marginal religions in Indonesia: Changing meanings of religious pluralism. Social Compass, 52(4), 473-493. https://sites.northwestern.edu/lawreligion/files/2017/06/HOWELL1-21u7zna.pdf

Human Rights Watch. (2017). Indonesia: No End to Abusive 'Virginity Tests'. https://www.hrw.org/news/2017/11/22/indonesia-no-end-abusive-virginity-tests. Accessed 9 January 2021.

Human Rights Watch. (2018). Indonesia: Medical Groups Silent on Abusive 'Virginity Tests'. https://www.hrw.org/news/2018/03/07/indonesia-medical-groups-silentabusive-virginity-tests. Accessed 17 January 2021.

Indiatoday. (2017). Indonesia: Two-finger test to check virginity still practiced during police Recruitment. https://www.indiatoday.in/fyi/story/indonesia-police-femalesrecruitement-virginity-1091909-2017-11-22. Accessed 21 January 2021.

Islam, Kazi. M. M., and Asadullah, M. Niaz. (2018). Gender stereotypes and education: A comparative content analysis of Malaysian, Indonesian, Pakistani and Bangladeshi school textbooks. PloS one, 13(1), 1-24. https://journals.plos.org/plosone/article?id=10.1371/journal.pone.0190807

Johnston, Melissa, P. (2017). Secondary data analysis: A method of which the time has come. Qualitative and quantitative methods in libraries, 3(3), 619-626. http://www.qqml-journal.net/index.php/qqml/article/view/169

Korstjens, Irene, and Moser, A. (2018). Series: Practical guidance to qualitative research. Part 4: Trustworthiness and publishing. European Journal of General Practice, 24(1), 120-124. https://www.tandfonline.com/doi/pdf/10.1080/13814788.2017.1375092

Laurent, Erick. (2005). Sexuality and human rights: An Asian perspective. Journal of Homosexuality, $48(3-4)$, https://www.tandfonline.com/doi/abs/10.1300/J082v48n03_09

McDermott, Josephine. (2015). Why does Indonesia demand that female military recruits are virgins?, BBC News, 19 May. HTTPs://www.bbc.com/news/world-asia32748248. Accessed 3 February 2021.

McDougal, Mires. S., Lasswell, Harold. D., and Chen, Lung-chu. (2018). Human rights and world public order: the basic policies of an international law of human dignity. Oxford University Press. London, UK. https://digitalcommons.nyls.edu/cgi/viewcontent.cgi?article=1056\&context=fac_boo ks

Moyn, Samuel. (2018). Not enough: Human rights in an unequal world. (1st ed) Harvard University Press. UK. https://www.hup.harvard.edu/catalog.php?isbn=9780674737563 O'Connell, Tom. (2018). Questionable virginity tests for female police and military recruits. Globe. 29 August. https://southeastasiaglobe.com/indonesia-virginity-tests-questionable/ 
Pratama, A.A. (2019). Politik Tubuh Perempuan: Studi Tes Genitalia pada Perekrutan Anggota Polisi Baru di Indonesia. International Journal of Demos, 1(3), 330-345. DOI: https://doi.org/10.37950/ijd.v1i3.26

Prisco, Joanna. (2018). Indonesian Policewomen Subjected to 'Virginity Testing,' Beauty Evaluations. Global Citizen, 22 October. https://www.globalcitizen.org/en/content/indonesian-policewomen-virginity-testing/

Ramadhan, Choky. R. (2018). Reforming Indonesian Rape Law: Adopting US Rape Shield Law in Excluding Predjudicial Evidence. Indon. L. Rev., 8(1), 63-90. https://media.neliti.com/media/publications/237897-none-52da24cb.pdf

Ruggiano, Nicole, and Perry, Tam. E. (2019). Conducting secondary analysis of qualitative data: Should we, can we, and how?. Qualitative Social Work, 18(1), 81-97. https://journals.sagepub.com/doi/pdf/10.1177/1473325017700701

Satterthwaite, Margaret. L. (2005). Crossing borders, claiming rights: using human rights law to empower women migrant workers. Yale Hum. Rts. \& Dev. LJ, 8, 1. http://digitalcommons.law.yale.edu/cgi/viewcontent.cgi?article $=1047 \&$ context $=$ yhrdl $\mathrm{j}$

Shedden, Melissa. (2018). Policewomen in Indonesia must go through virginity testing. New York Post, 23 October. https://nypost.com/2018/10/23/policewomen-inindonesia-must-go-through-virginity-testing/

Siddhartha, Amanda. (2018). Virginity tests put Indonesian women off military service; often performed by men, they are seen as degrading. South China Morning Post, 10 August. $\quad$ https://www.scmp.com/lifestyle/article/2160023/virginity-tests-putindonesian-women-military-service-often-performed-men

The Jakarta Post. (2017). Indonesia urged to end discriminatory virginity test for female security force applicants. https://www.thejakartapost.com/news/2017/11/23/indonesia-urged-to-enddiscriminatory-virginity-test-for-female-security-force-applicants.html

The Journal. (2014). Female police recruits in Indonesia are subjected to virginity tests, https://www.thejournal.ie/indonesia-police-1789470-Nov2014/

The Wire (2020). Number of Women in Police Force Rises, but Falls Well Short of Mandated 33\% Target: Govt Data. https://thewire.in/women/number-of-women-inpolice-force-rises-but-falls-short-of-the-mandated-33-target-govt-data

United Nations. (2021). Human Rights. https://www.un.org/en/sections/issuesdepth/human-rights/

United Nations. (2021). Protect Human Rights. https://www.un.org/en/sections/what-wedo/protect-human-rights/

Vogel, Frank. (2000). Islamic law and the legal system of Saudi: Studies of Saudi Arabia (Vol.8). Brill. https://brill.com/view/title/1385

Wibawa, Tasha. (2018). Indonesian policewomen measured through 'purity and beauty', subjected to virginity testing. ABC News, 20 October. https://www.abc.net.au/news/2018-10-20/indonesian-policewomen-must-be-prettysubjected-to

tests/10333762\#: :text=Virginity\%20testing\%20is\%20no\%20longer,key\%20part\%2 0of\%20police\%20recruitment

World Health Organization. (2017). Transformative accountability for adolescents: accountability for the health and human rights of women, children and adolescents in the $2030 \quad$ agenda. World Health Organization.https://apps.who.int/iris/bitstream/handle/10665/259699/978924151299 2-eng.pdf 
Yi, Beh. L. (2015). Indonesian military insists on virginity tests to determine 'naughty' female recruits. The Guardian, 14 May. https://www.theguardian.com/world/2015/may/14/indonesian-military-insists-onvirginity-tests-to-determine-naughty-female-recruits

Zechenter, Elizabeth. M. (1997). In the name of culture: Cultural relativism and the abuse of the individual. Journal of Anthropological Research, 53(3), 319-347. DOI: 10.1086/jar.53.3.3630957 